\title{
Lastnoročne opombe in korekture Jana z Jenštejna v njegovem epistolariju
}

Ključne besede: Jan z Jenštejna, epistolarij, avtograf, avtorjevi popravki, 14. stoletje, latinska besedila na Češkem

DOI: $10.4312 /$ ars.8.2.72-86

V srednjeveškem gradivu le redkokdaj naletimo na lastnoročno napisana dela učenjakov ali drugih ustvarjalcev. Največkrat jih srečamo v okvirih njihovega delovanja na univerzah, saj je bilo med tistimi, ki so študirali, vedno veliko takih, ki so si za cilj zadali, da bodo tudi sami pisali, nekateri pa so z leti v resnici postali učenjaki. Tisti, ki jim je med študijem denarno bolj trda predla, so si vsaj sprva morali sami prepisati potrebna študijska besedila, v katera so včasih vključili tudi koncepte lastnih starejših besedil. To je počel npr. Adalbertus Ranconis De Ericinio (Vojtěch Raňkův z Ježova), ki je pozneje postal scholasticus metropolitanskega kapitlja v Pragi; v letih 1346-1369 je študiral na pariški univerzi in pozneje predaval. Svoj rokopis je prinesel $\mathrm{v}$ domovino in je danes shranjen $\mathrm{v}$ knjižnici stolnega kapitlja, kjer je Adalbert deloval od svoje vrnitve v Prago do smrti leta 1388. ${ }^{1}$ Tudi Jan Hus, ena najbolj znanih osebnosti češkega poznega srednjega veka, je sprva sam prepisoval besedila, ki so ga zanimala, ter jih sproti komentiral. Na Husa so vplivali nekateri traktati Johna Wycliffa, ki so se ohranili v rokopisu, sedaj hranjenem v Kraljevi knjižnici v Stockholmu. ${ }^{2}$ Prava zakladnica z možnimi avtografi univerzitetnih magistrov 15. stoletja je liber decanorum filozofske fakultete v Pragi. ${ }^{3} \mathrm{Na}$ podlagi tega kodeksa je bilo mogoče še v drugih rokopisih opredeliti oziroma prepoznati avtografe zagovornikov in nasprotnikov utrakvizma - kot so magister Johann von Rokycany (Jan Rokycana), Johann von Příbram (Jan z Př́ibrami) ali Wenzel Koranda (Václav Koranda z Plzně). Vendar liber decanorum še ni sistematično raziskan. ${ }^{4}$

1 Praga, Knihovna pražské metropolitní kapituly (Knjižnica praškega metropolitanskega kapitlja), N 8. Prim.: Kadlec, predgovor k Adalbertovim spisom (1971), 71-74.

2 Stockholm, Kungliga Biblioteket (Kraljeva knjižnica), Codex Holmensis A 164. Prim.: Spunar (1959), 235-238, (1960), 116-122; Molnár (1959), 239-244.

3 Praga, Národní knihovna České republiky (Narodna knjižnica Češke republike), Sign. VIII E 7. Prim.: Marek, reprodukcija na notranjem predlistu.

4 Liber decanorum facultatis philosophicae Universitatis Pragensis ab anno Christi 1367 usque ad annum 1585, Pragae 1983 (faksimile). 
Svojo, nekolikanj posebno kategorijo lastnoročnih zapisov predstavljajo besedila, ki so neposredno avtorjevo delo. Že na začetku 15. stoletja naletimo v češkem okolju na izjemo. Gre za avtograf Jacobella de Mies (Jakoubek ze Stř́bra), enega vodilnih magistrov $\mathrm{v}$ zgodnjem obdobju husitske univerze in vodilnega husitskega teologa: pred nedavnim je bil odkrit in identificiran koncept njegovega besedila, znanega kot Quaestio, o obhajilu pod obema podobama. ${ }^{5}$

Univerzitetna Quaestio ni seveda nič drugega kot krajše besedilo, pripravljeno za govorjeno predavanje in diskusijo. Enak namen je značilen tudi (in predvsem) za pridižne osnutke, zlasti tiste, ki so bili zapisani kot osnova za v resnici povedane pridige in niso bili zapisani $z$ literarnim namenom. Zato jih pogosteje najdemo kot zapise $\mathrm{z}$ osebnimi nagibi in za lastno uporabo, ko je avtor pridigo šele pripravljal. ${ }^{6}$ Pridigar, ki je svoje nagovore sicer vestno pripravil v pisni obliki, svojih besedil po uporabi povečini ni ohranil. Večina pridižnih zbirk, ki so jih pripravili znameniti češki reformatorji, je nastala bodisi kot literarno delo ali pa gre za zapise poslušalcev, ki so bili prisotni med nagovorom.

Avtografi ustvarjalcev in pridigarjev so bili zapisani v običajni, prevladujoči pisavi njihovega časa, a vselej v nagli, površni obliki in s številnimi okrajšavami, kar naj bi pripomoglo $\mathrm{k}$ ohranjanju avtorjevega miselnega toka. Nekaj takega smo že videli $\mathrm{v}$ znanem avtografu Tomaža Akvinskega. ${ }^{7}$

Posebne okoliščine v pripravljanju dokončne verzije besedila pa nastopijo tudi takrat, ko je srednjeveški avtor sicer imel univerzitetno izobrazbo, vendar je z leti dosegel višji družbeni položaj; zato je naročil prepis svojih del - že zaradi časovnih omejitev in prestižnih okoliščin - pri pomožnem pisarju iz bližine ali kar pri poklicnem kopistu. Svoja dela je lahko tudi narekoval - sicer bi se avtorski osnutki utegnili ohraniti - ali pa je bila zasnova ob nastanku kakovostnega prepisa uničena. Večino srednjeveških del poznamo le prek prepisov, pri čemer so primarni prepisi redkost, oziroma izjema. Tudi poznejša dela Adalberta Ranconija z Ježova, ki so že nastala v Pragi, so znana po takšnih prepisih.

Sem in tja so se ohranili rokopisni spomeniki, ki jih je sicer napisal poklicni prepisovalec, vendar jih je zatem avtor sam še korigiral. ${ }^{8} \mathrm{O}$ avtorskih dopolnilih in

5 Povezavo med nauki in spisi utrakvističnih magistrov raziskuje Jindřich Marek.

6 Opozorimo lahko na lastnoročno napisane osnutke pridig papeža Janeza XXII.; prim.: Trottmann (2000), 512-521 in bibliografsko prilogo.

7 Prim.: Steffens (1909), slikovna priloga št. 98 (leto 1286).

8 Podoben primer avtorske korekture prvotnega besedila je v Vatikanu hranjeni rokopis Zbraslavske kronike (Königssaaler Chronik) Petra Žitavskega (Peter von Zittau), ki je hkrati tudi avtograf izvirnega, prav tako popravljenega besedila. - Temeljno analizo je prispevala Pumprova (2012), 239-263. - O pojavu številnih avtografov med kronističnimi zapisi gl. J. P. Gumbert, 2013, 39-48. 
besedilnih korekturah lahko sklepamo - kadar avtografa ne poznamo že od vsega začetka - na temelju vsebine oziroma zvena besedila, skladnosti vsebine z razvojem misli in stilistike popravljenega dela. Resnični znanstvenik ali literat, ki bi bil avtorsko tesno povezan $\mathrm{z}$ bistvom svojega dela, bi besedilo tudi v 14. stoletju pred dokončnim prepisom nedvomno še enkrat prebral in ga po potrebi dopolnil ali popravil, prav tako, kot počnemo v 21. stoletju. In podobno kot sedaj ne shranjujemo popravljenih rokopisov, potem ko je knjiga natisnjena, smemo domnevati, da so tako ravnali tudi $\mathrm{v}$ srednjem veku, le da je bistvena razlika v tem, da je takrat imela bistveno večjo težo osebna odločitev avtorja, kakšna bo usoda besedila, kakor danes.

Proces, ko je avtor, oseba na visokem položaju, postopoma popravljal in dopolnjeval svoje besedilo pred objavo in je dokončno verzijo šele nato izročil poklicnim prepisovalcem, je bil nedvomno dosti bolj utečen, kakor lahko spričo števila ohranjenih primarnih izvodov danes dokažemo. Primarni rokopisi so zaradi svoje enkratnosti in tekstovne kakovosti, ki je bila lastna samo avtorju, resnična redkost. Precej utemeljena je domneva, da so resnično originalna in redigirana besedila uničili po nastanku merodajnega prepisa. To se je zgodilo, ker so bila besedila $\mathrm{z}$ avtorskimi popravki nečitljiva ali nepregledna že za sodobnike, nemara pa se je tako zgodilo iz prestižnih nagibov samega avtorja.

Mislim, da lahko takšno korigirano osnovo za dokončno in javnosti namenjeno izdelavo rokopisa prepoznamo $\mathrm{v}$ pisemski zbirki praškega nadškofa Jana $\mathrm{z}$ Jenštejna, znanega kot Codex Epistolaris Johannis de Jenzenstein. ${ }^{9}$ Čeprav pri korekturah in dopolnitvah nikjer ni mogoče najti nadškofovega imena, niti njegovega podpisa ne, sem $\mathrm{v}$ to kljub vsemu prepričana - in to svoje prepričanje nameravam utemeljiti $\mathrm{v}$ nadaljevanju.

Jan z Jenštejna (1347-1400, Slika 1) je bil sin kraljevega notarja Pavla z Jenštejna in nečak praškega nadškofa Očka z Vlašima (1364-1378). Družina je socialni vzpon in bogastvo dosegla že $\mathrm{v}$ času teh dveh mož. Zato ni bilo vprašanje, ali Jana, ki mu je bila namenjena kariera v cerkvenem okrilju, poslati študirat na evropske univerze. Najprej je študiral na artistični fakulteti v Pragi, nato pa na univerzah v Padovi (1371), Bologni, Montpellieru (1374) in Parizu (1375-1376). Po študiju in bivanju pri kuriji

9 Loserth je to besedilo objavil pod naslovom Der Codex epistolaris des Erzbischofs von Prag Johann von Jenzenstein. Izdaja kaže vse značilnosti nepopolne edicijske tehnike, ker je nekatera besedila skrajšal, obstranske pripombe zvečine izpustil, druge krati pa je (največkrat medvrstične glose) vključil neposredno v besedilo, ne da bi označil, da gre za dodano korekturo. V Loserthovi ediciji tudi ni zaznamka, kaj je v besedilu prečrtano. Rokopis je danes hranjen v: Praga, Národní archiv (Narodni arhiv), Fond češke dvorne pisarne, cod. 147 (prej Državni centralni arhiv, zbirka: Rokopisi različnih provenienc, rkp. 2449). Rokopis ima tudi novejšo foliacijo, Loserth je uporabljal starejšo, ki je v desnem zgornjem vogalu strani; novejša in popolnejša foliacija, ki je vedno za eno številko višja, je napisana na levem spodnjem robu. Ob posameznih folijih je s svinčnikom dodana oznaka, ki opozarja na številke v Loserthovi ediciji. 
v Avignonu in drugih krajih kulturne Evrope se je leta 1376 vrnil kot novoimenovani meissenski škof, že leta 1378 pa je po abdikaciji svojega strica postal nadškof v Pragi. Hkrati je postal kancler novookronanega češkega kralja Vaclava (do leta 1384). Večina pisem, ohranjenih v zbirki Codex Epistolaris, je iz tega časa, v čas med letoma 1374 in 1384 pa spadajo vsaj tista, ki jih je mogoče datirati. V zbirko sta dodana še dva napol uradna spisa, ki sta bila napisana v letih 1386-1388 zaradi javnega interesa, se je pa nadškof zanju zanimal iz osebnih razlogov. ${ }^{10}$

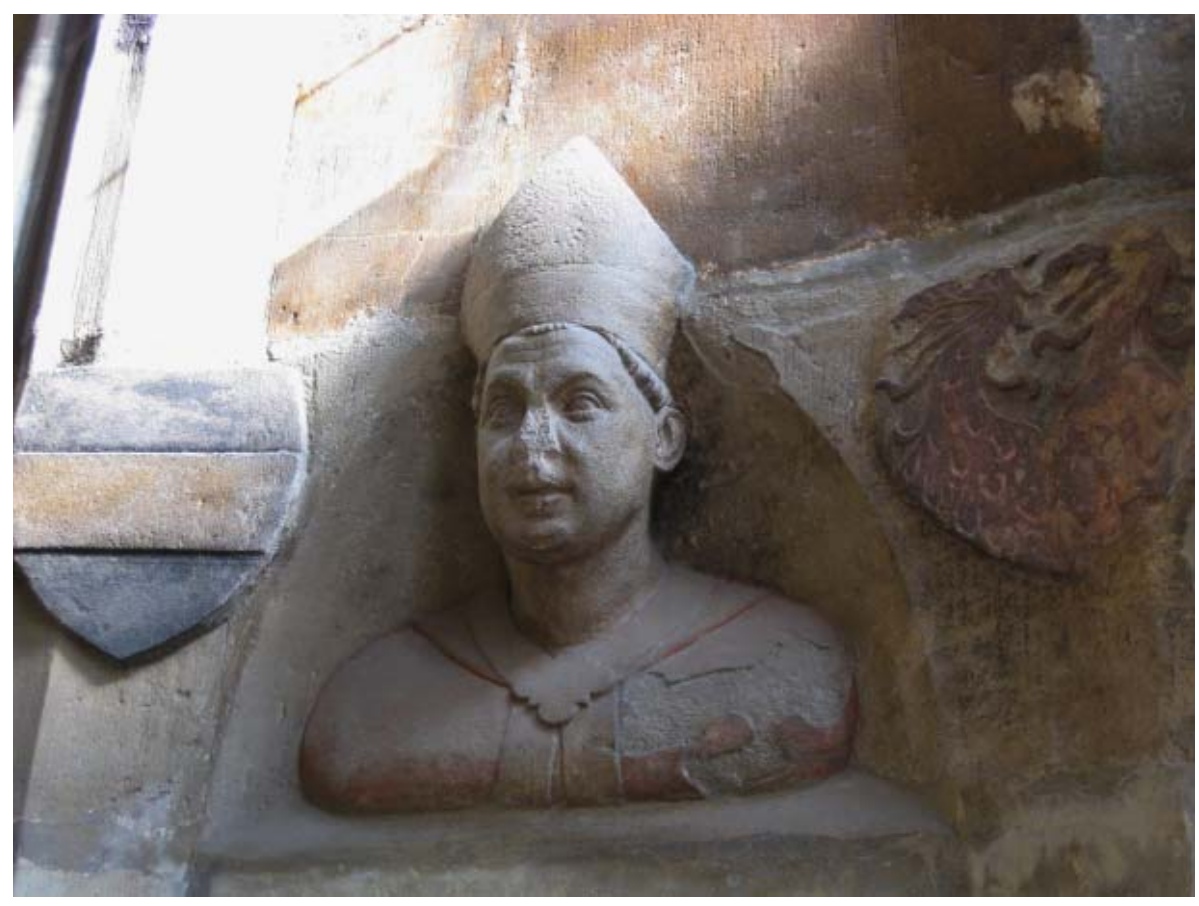

Slika 1: Peter Parler in delavnica:

Portretno doprsje Jana z Jenštejna, 1370-1379,

Praga, stolnica sv. Vida.

Pisemska besedila predstavljajo le majhen del tekstov, ki jih je napisal Jan z Jenštejna. Dobro znani so tudi njegovi teološki in meditativni traktati ter liturgična besedila (oficiji), himne in pridige, posebej marijanske. ${ }^{11}$ Pisal je brez prekinitev vse

10 Domnevno kronološko zaporedje pisem je predlagal že Loserth, op. 9, 94-98.

11 Izbor iz spisov Jana z Jenštejna je objavil Weltsch (1968); popolno izdajo Jenštejnovih pisem vključno z epistolarijem - je pripravljal Polc, a ga je prehitela smrt (2003). Ob priložnosti sem lahko pregledala besedilo, ki ga je pripravljal za objavo epistolarija, da bi videla, ali se je ukvarjal z zunanjo podobo rokopisa, in da bi ugotovila, ali je upošteval možnost, da je Jenštejn sam korigiral besedila. Glede obojega sem prišla do negativnega sklepa. Polc se je pri pripravah Jenštejnove biografije osredotočil predvsem na vsebino besedil, tudi pisem. To je raziskoval že prej in je posebne teme objavil v nekaterih razpravah, s pismi pa se je ukvarjal v sestavku »Zakaj nadškofa Jana z Jenštejna niso vrgli v Vltavo« (1995). 
svoje življenje; literarnemu delu pa se je intenzivneje posvetil šele leta 1396, potem ko se je odpovedal službi praškega nadškofa (umrl je leta 1400). ${ }^{12}$ Glede na njegov intelekt, položaj in materialno stanje lahko domnevamo, da si je kot literarno dejaven avtor privoščil pomoč pisarja, morda svojega kaplana, si pa zaradi svojih ustvarjalnih nagibov ni dovolil, da bi prepis besedil v celoti prepustil samo njemu. Zanj je bilo seveda samoumevno, da je prepisano besedilo - preden je rokopis izročil javnosti $\mathrm{v}$ branje - sam pregledal in popravil.

Če hočemo z vsaj primerno mero verjetnosti dokazati, da je rokopis z zbirko pisem Jana $\mathrm{z}$ Jenštejna eden redkih ohranjenih kodeksov posebnega tipa, $\mathrm{v}$ katerem so korigirani prepisi izvirnih besedil ter je bil predviden kot osnova za dokončen čistopis po objavi lastnega besedila, je treba pričeti $z$ analiziranjem zunanje oblike in ureditve rokopisa, ki ga imamo na voljo.

$\mathrm{V}$ primerjavi z rokopisom, ki je bil bogato slikarsko okrašen in vsebuje druga besedila Jana $\mathrm{z}$ Jenštejna ter je hranjen $\mathrm{v}$ Vatikanski apostolski biblioteki, ${ }^{13}$ je epistolarij po videzu skromen papirni kodeks, $\mathrm{v}$ katerem je dosti besedila prečrtanega in mnogo dopolnjenega. Pred leti je Loserth (Loserth, 269) v kodeksu zajeta pisma opredelil kot koncepte. S tem ni mislil, da je rokopis nastal zaradi knjigoveških odločitev in združitve besedil, ki so se ohranila oziroma nastala kot izvirni koncepti, ampak da je prepis pisem znotraj kodeksa dobil značaj konceptov takrat, ko so bila - zvezana v obliko kodeksa - deležna tekstovnih popravkov. Večino pisem je v pet konvolutov prepisal en sam kopist, vendar ne naenkrat, ampak očitno $\mathrm{v}$ kratkih presledkih $\mathrm{v}$ procesu prepisovanja posameznih pisem. Pisar ${ }^{14}$ ni bil ravno vajen rednega in pogostega pisanja, njegova pisava je šolska, skrbno oblikovana in nagnjena bastarda 14. stoletja. Le izjemoma je na zunanjem robu dodal popravek svojega besedila, kjer je pri prepisu očitno izpustil eno vrstico (fol. 43r, št. 53). Epistolarij vsebuje 77 pisem, ki so urejena v pet različno velikih konvolutov, ${ }^{15}$ kjer je sem in tja kakšno pismo ali del pisma v poškodovanem konvolutu izrezano. Oblikovanje strani je enako v vseh konvolutih, ki jih je prepisal glavni kopist, torej v prvem, drugem, četrtem in petem, ureditev tretjega konvoluta pa

12 Strukturirani seznam spisov Jana z Jenštejna je - skupaj s sklici na izdaje in strokovno literaturo objavil Polc (Dictionnaire de Spiritualité VIII); gl. ponatis (1999) in Repertorium P. Spunarja.

13 Biblioteca apostolica Vaticana, Vat. lat. 1122. Po vsem sodeč gre pri vatikanskem rokopisu v okviru Jenštejnovih spisov za tisti prepis, ki se je oprl na predlogo z Jenštejnovimi provizoričnimi korekturami.

14 V Emlerjevi izdaji Vita Johannis de Jenczenstein je v zadnjem poglavju (468) zapisano to in ono o Jenštejnovih čudežih, med drugim o nekem Matiju, ki naj bi postal nadškofov kaplan. Ni izključeno, da je bil Matija pri nadškofu do njegovega zadnjega dne. Kljub temu pa ga brez dodatnih raziskav in dokumentov ne moremo poistovetiti s prepisovalcem epistolarija.

15 Konvolut je sestav posameznih listov, ki so speti ali sešiti; posamični konvolut je lahko tudi samostojen kodeks (op. N. G.). 
se razlikuje. ${ }^{16}$ Poleg zunanje ureditve se konvoluti razlikujejo tudi glede vsebinskega sestava pisem, kar je odvisno od tega, ali so namenjena javnosti ali zasebnemu branju; v okviru posameznega konvoluta pa si pisma sledijo v sorazmerno natančnem časovnem zaporedju. ${ }^{17}$ Tretji konvolut, $\mathrm{v}$ katerem je pisal še neki drug kopist (torej fol. 23-38), je edini, kjer najdemo korekture, ki jih ni vnesel ne kopist ne tisti, ki mu rečemo »korektorjeva roka«.

Kodeks ni bil zvezan prej kot v sredini 15. stoletja. Takrat so rokopisu dodali za Jenštejnovim epistolarijem (ki se konča s folijem 54) - še prepis nekaterih dokumentov iz časa Karla IV., ki se nanašajo na ozemlje Meissna, Ogrske in Brandenburga (fol. 55-102). ${ }^{18}$ Ta sklop dokumentov pa je prepisal eden od kopistov $\mathrm{v}$ pisarni. Tudi vodni znaki v papirju so drugačni od tistih v sicer povsem enotnem papirju epistolarija. ${ }^{19}$

$\mathrm{V}$ prvem, drugem, četrtem in petem konvolutu epistolarija Jana z Jenštejna (Slika 2 in Slika 3) so popravki in dopolnila v besedilu, vse pa je pisala ena sama roka. Korekture so tako medvrstične kot obstranske. Medvrstični popravki ponavadi pomenijo spremembo povedanega in so napisani nad prvotno zapisanimi in nato prečrtanimi besedami. Takšen primer je na fol. $7 \mathrm{v}$, kjer je maioribus turbacionum spremenjeno $\mathrm{v}$ non minoribus turbacionum. Na fol. 16r je nad prečrtanim exicium napisano torsionem, na fol. $53 \mathrm{v}$ piše nad dispensator nova beseda, defensor, glagola videmur in communicare pa sta zamenjali besedi cogimur in destituare. Izjemoma najdemo tudi stvarne popravke, npr. imen, kjer je $\mathrm{v}$ pismih rektorju in magistrom kolegija Karlove univerze na fol. 11r namesto prvotne fraze prout Machabei ... dixerunt kot korektura zapisano ime Matathias.

16 V konvolutu so različne pisarske roke; gre za konvolut, ki je sestavljen iz sedanjih folijev $23 \mathrm{v}-38 \mathrm{v}$. $\mathrm{V}$ vsebinskem in formalnem pogledu pa se ta pisma (pri Loserthu št. 39-45) razlikujejo od preostalih zaradi njihove obče veljavnosti, prejemnikovega ugleda in očitno tudi mlajšega datuma nastanka glede na prvotni zapis. Pri teh pismih ne najdemo nobenega popravka, ne oziraje se na roko.

17 Kronološko približno urejen seznam vseh pisem (seveda ne oziraje se na konvolute) je sestavil že Loserth, 294-298, v uvodu k svoji izdaji epistolarija. Njegove datacije lahko danes marsikdaj zapišemo natančneje.

18 Na zgornjem robu pergamentnega folija, ki služi za ovitek, se je ohranil sorazmerno zabrisan napis v humanistični pisavi: Epistolae Cancellariae bohemicae / sub Wenceslao rege; na notranji strani pa z roko, ki pripada nekako 15. stoletju: Epistule diverse cum contractibus ...

19 V epistolariju je bil uporabljen izključno papir z vodnim znakom volovske glave z velikimi usločenimi rogovi, med katerimi se dviguje križ. To ne velja za del kodeksa, kjer so zapisi iz kraljeve pisarne. 


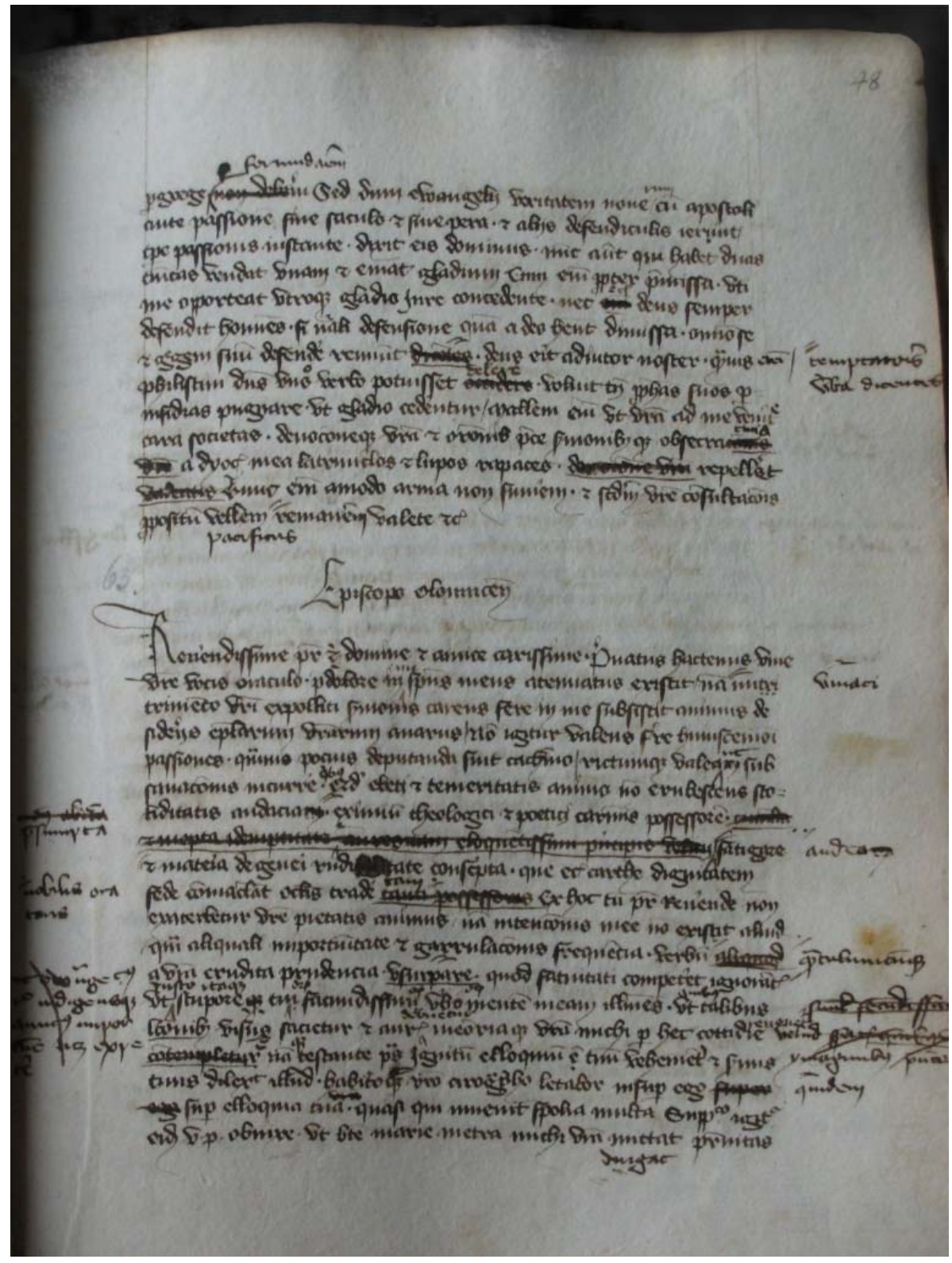

Slika 2: Národní archiv Praha, Česká dvorská kancelář, cod. 147, fol. 78r: Pismo Jana z Jenštejna nadškofu v Olomucu z lastnoročnimi popravki in dopolnili. 


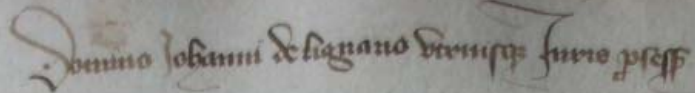

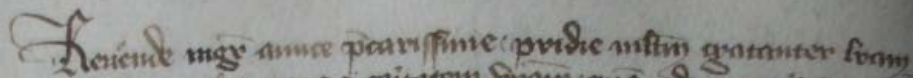

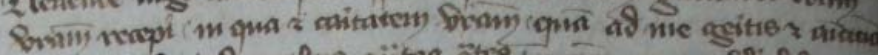

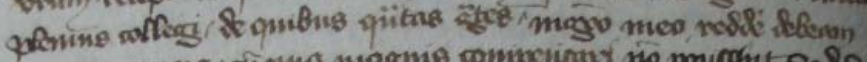

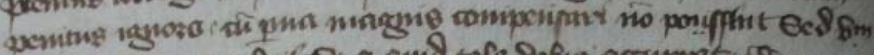

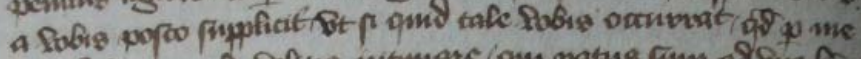

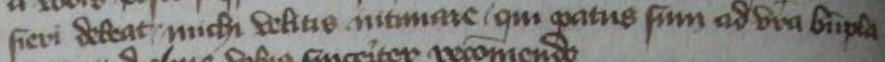

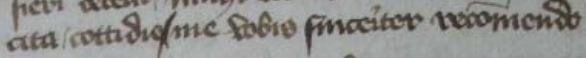

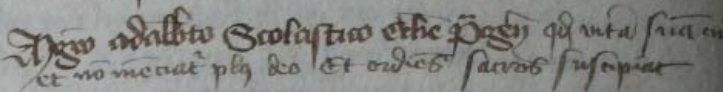

7.

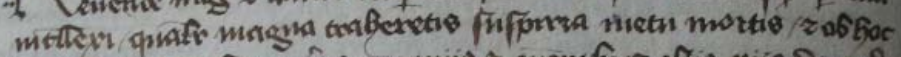

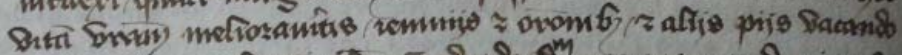

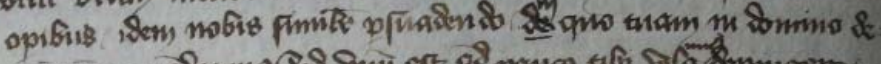

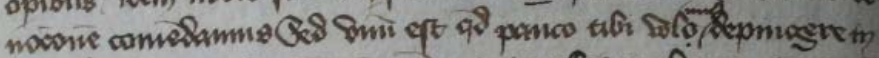

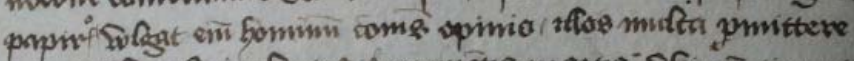

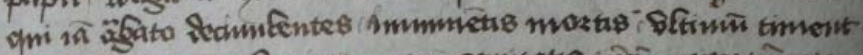

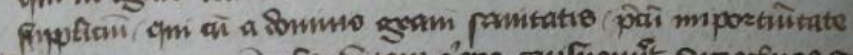

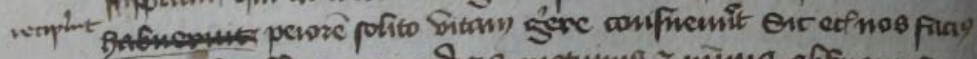

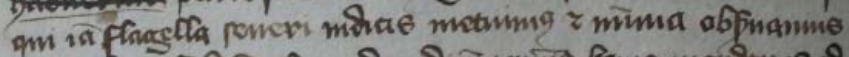

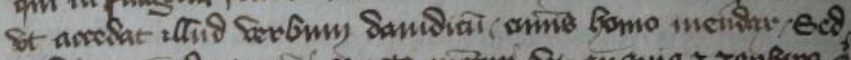

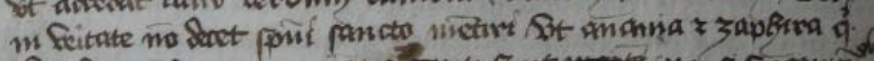

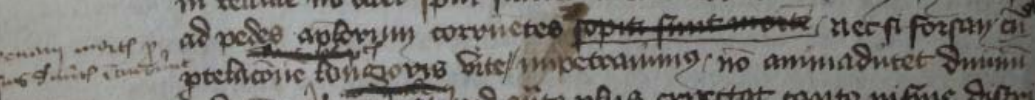

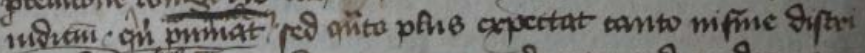

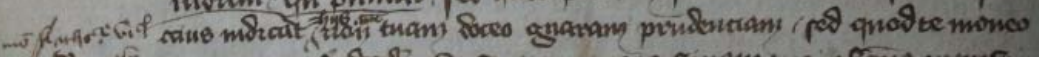

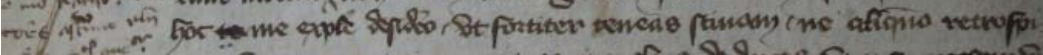

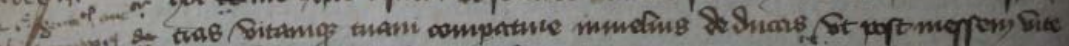

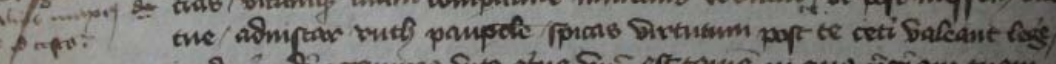

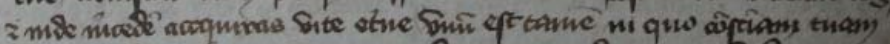

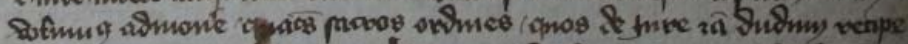

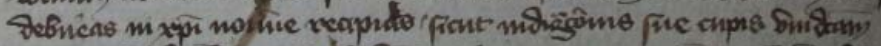

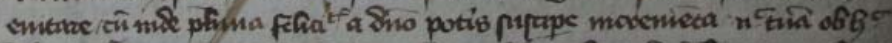

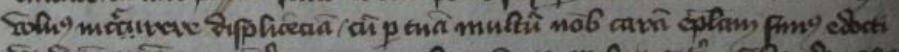

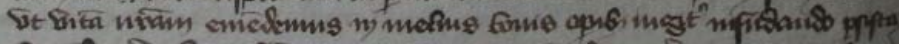

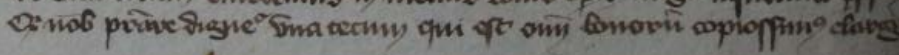

Slika 3: Národní archiv Praha, Česká dvorská kanceláŕ, cod.147, fol. 54v:

Pismo Jana z Jenštejna praškemu sholastiku Vojtěchu Raňkovu z Ježova z lastnoročnimi popravki in dopolnili v naslovu in besedilu. 
Na margine zapisane spremembe so seveda spet lahko le posamezne besede, lahko pa so tudi daljše fraze in $\mathrm{v}$ besedilo vnašajo nove formulacije, $\mathrm{s}$ katerimi se prvotna misel razpre, dopolni: $v$ pismu, naslovljenem na oficiala Boreša, je bil na fol. $16 \mathrm{r} v$ del stavka ... aut cuiuscumque morbi alterius lesionem et tamen gladio occumbere metuis ... za substantivom lesionem vrinjen podredni stavek quibus humana facile vita dissolvitur. Pogosteje pa gre le za bolj eleganten izraz, ki ima enak smisel; takšen primer najdemo v Janovem pismu mlajšemu bratu Vaclavu, ki je tedaj študiral v Padovi, kjer je prvotno frazo est enim, quo tue fraternitati consulimus nadomestila na prostem robu napisana fraza est enim, quo tibi consulendum gliscimus (fol. 10r).

Vstavki so zvečine zaznamovani z grafičnim znamenjem, ki pa ga včasih pogrešamo in zato ne vemo natančno, kam je avtor nameraval vključiti svoje dopolnilo. Poleg tega pa je treba upoštevati še naslednje: iz različnih odtenkov tinte je razvidno, da je Jan z Jenštejna prečrtal marsikatero korektorjevo dopolnilo. Te korekture in dopolnitve niso enakomerno prisotne, njihova pogostost se spreminja, včasih gre za detajle, včasih pa je izvirno besedilo tako rekoč predelano. Pomembne tekstovne spremembe so doletele zlasti pisma petega konvoluta, kjer so predvsem prepisi najstarejših pisem, ki jih je Jan pisal v mladosti, v času študijskih potovanj, ter jih poslal najbližjim prijateljem in sorodnikom.

Za ponazoritev navedimo spremembe v pismu na začetku petega konvoluta, ki ga je poslal proštu Wenzlu v Meissen, ki je bil imenovan na to mesto leta 1375 (fol. 46r, Loserth, št. 55). Vsa pomembna mesta so bila nekajkrat spremenjena. Po uvodnih stavkih in citiranju psalmov se je osrednji del besedila pričel s stavkom: ... quare qui prius (korekturno znamenje) elingwis (nad besedo piše . pene et fueram) eam nunc laxare cogor linguam in verba oris mei per supplicacione, imprecacione, pro paciencia discplicencia uti convenit. Korekturno znamenje povezuje $\mathrm{z}$ dopolnilom na margini paternis piisque monitibus. Za besedami uti convenit, s katerimi se konča bistveni del besedila, sledi na prostem robu zapisan dodatek malens quam ipso corde diligo, verbis licet amaris, quantum Deus dedit, non emendem; a tudi ta dodatek je bil prečrtan. Na koncu tega folija lahko preberemo: qui aut curtus aut longus, artus vel superfluus in te (korekturno znamenje) apparet. Zadnja beseda je prečrtana in nad njo piše cernitur. $\mathrm{Na}$ prostem robu se korekturno sidro povezuje z vstavkom: nullo modo potest statui convenire et ut clericus teipsum conspiceris intuere nunc speculum tuis nocuis quam meis luminibus (oculis). In celoten dodatek je bil ponovno prečrtan. Le kdo bi lahko tako ravnal s prvotnim besedilom?

Navedimo še en primer korekture v tem, meissenskemu proštu poslanem pismu, v katerem ne manjka popravkov. Samo ta korektura je v vsem epistolariju subjektivno 
stilizirana. ${ }^{20}$ Popravek je vstavljen v tisti tretjini pisma, kjer se prvotni stavek glasi: in fructuosumque te reperiens indigentem faciat et egente. Za besedo fructuosum so besede faciat se fugere prečrtane, na njihovem mestu pa so na desnem in nekoliko obrezanem robu besede dopolnjene $\mathrm{z}$ naslednjimi: sed unde michi vi[te] tue tam indecentis fluxusque veniat status forsitan ///. Vendar je celotno pismo osebno oblikovano, tako da je zaimek michi tu povsem na mestu. A ostaja vprašanje, ali si je korektor - katerikoli že - dovolil, da je bistveno posegel $v$ besedilo in je še živečemu avtorju pisma, Janu $\mathrm{z}$ Jenštejna, $v$ resnici podtaknil prvoosebno obliko.

Za presojanje avtorstva popravkov so posebej pomembni tisti primeri, kjer se je korektorju zdelo, da so izrazi v izvirnem besedilu premočni in jih je včasih prečrtal, ne da bi vnesel kakršnokoli nadomestno besedo. Tako se je zgodilo na fol. 18r, in sicer v pismu, naslovljenem na papeža Urbana VI.; prvotna sklepna formula je bila zapisana $\mathrm{v}$ obliki me, humilem creaturam vestram, quem post Deum alia non reperitur, humiliter recommendo, vendar je del humilem ... reperitur korektor navsezadnje prečrtal in izpustil.

$\mathrm{Na}$ tem mestu ne bi imelo smisla navajati vseh popravkov in sprememb $\mathrm{v}$ pismih, to naj ostane za prihodnjo kritično izdajo. Izbrani primeri naj bi le nakazali značaj korektur, ki bolj posegajo v besedilo, kot bi si lahko dovolil navaden korektor. Število teh obsežnih posegov je očitno odvisno tudi od izrazitosti osebnega tona $\mathrm{v}$ posameznem pismu: čim bolj je način izražanja oseben, toliko več popravkov je $\mathrm{v}$ pismu. Prav nasprotno pa je v pismih, ki so naslovljena na gosposko ali deželne upravitelje (npr. mejni grof Prokop), s katerimi ni imel ravno prijateljskih stikov, komaj kakšen popravek. Poleg takih izrazitih popravkov besedila in vrinjenih misli pa je "korektorjeva roka" - v tretjem in petem konvolutu - dodala dopolnila v rubricirane naslove, ki so na začetkih posameznih pisem. Glavni kopist je napisal zgolj imena naslovnikov, »korektor « pa je dodal ključne besede, v katere je zajel vsebino. Npr.: magistro Borssoni, archidiacono Bechinesi / cur tempore pestilencie auffugit ad partes alienas. »Korektor« se je podrobneje ukvarjal s pismi iz mladih let, ki jih je avtor namenil osebam, ki so mu bile blizu.

Poleg delnih popravkov in preureditev so $\mathrm{v}$ celotnem kodeksu nekatere korekture in dopolnitve prečrtane. Kadar je bilo pismo izpuščeno iz celote, je »korektor " pismo v celoti prečrtal in povečini dodal še znamenje, ki pove, da je pismo izpustil. ${ }^{21}$ Vnovič ima

20 Prim. Loserthovo enoto št. 55.

21 Gre za kombinacijo kroga (majuskulni $O$ - ommissum), nad katerim je napisana minuskulna črka oziroma črke glede na zaporedje $\mathrm{v}$ abecedi. V nasprotju $\mathrm{z}$ Loserthom, ki je v svoji izdaji izpustil prečrtana pisma, jih je »korektor « uvrstil v svojo načrtovano izdajo. Gre za pisma št. 29 (fol. 18v), št. 49 in 50 (fol. 41v). - Samo znamenje $O$, vendar brez dodanih minuskul, je pri pismu št. 45 (fol. 36v), ker je bilo to pismo na novo prepisano na fol. 44r z oznako vacat. Pri pismih št. 60 in 61 (fol. 48r) vidimo le prečrtanje brez znaka za izpustitev, prav nasprotno pa je pri pismu št. 65 (fol. 50r): 
večina pisem zasebni značaj. ${ }^{22}$ Prečrtanje pisma in znak za izpustitev torej pomenita izločitev nekega besedila iz celotne zbirke in hkrati opozarjata, da je bil načrtovan dokončni prepis epistolarija.

Iz predstavljenih okoliščin in očitnega korektorjevega osebnega odnosa do besedila oziroma do naslovnikov izvirnih pisem, v katere je posegal bistveno obsežneje, kot se dogaja pri primerljivem delu, so se mi izrisali naslednji sklepi:

V rokopisu Jenštejnovega epistolarija, ki je hranjen v Narodnem arhivu v Pragi, so se ohranile avtorske korekture, lastnoročni posegi v besedilo, ki so slogovno enake $\mathrm{v}$ posameznih pismih in $\mathrm{v}$ celotnem epistolariju ter jih je napisal stilist, to pa ni mogel biti nihče drug kot Jan $\mathrm{z}$ Jenštejna. Kodeks je zato eden redkih ohranjenih rokopisov $\mathrm{z}$ besedilom, ki ga je popravljal avtor sam, vendar ni bilo besedilo nikoli prepisano $\mathrm{v}$ dokončno obliko. ${ }^{23}$

Pisarski »videz«, »izraz« korektorjeve roke, je mogoče hoten, da ustreza namenu korekture: pisava mora biti nesporno berljiva, poseben kaligrafski značaj pa pri tem ni pomemben. Kljub temu posebnemu namenu je Jenštejn pisal z izurjeno roko, uporabljal je horizontalno poudarjeno gotsko kurzivo, včasih z enklavami (= ena črka v drugi), z odprtimi očesi in okroglinami $(e, b)$, hkrati pa je ohranil poenostavljene, načeloma minuskulne oblike posameznih črk ( $g$, okrogli $s$ ). Značilni sta ozka in glede na vrstico pravokotno zapisana zanka črk $l$ in $b$ ter dosledno kurzivna oblika odprtega $r$.

Pisarska oblika avtorskih korektur se povsem ujema $\mathrm{z}$ dejstvom, da je bil Jan $\mathrm{z}$ Jenštejna - ki je bil v tretji četrtini 14. stoletja kraljevi kancler - tudi literat, človek, ki je pisanje v resnici uporabljal za zapisovanje svojih misli. $V$ tem primeru pa je spoštoval tudi pravilo, da ni nujno, da mora biti besedilo, ki ga je napisal, čitljivo za vse, vendar pa za tiste, ki jih to zanima.

Prevedla Nataša Golob

označeno je samo $O-f$, vendar pismo ni prečrtano, pri pismu št. 35 (fol. 21r) pa je le $O$ kot oznaka za ommissum, ni pa zaporedne črke.

22 Npr. pismo sestri, poslano iz Bologne, fol. 48v, Loserth št. 61, pa tudi pisma svojemu bratu.

23 To je očitno povezano $\mathrm{z}$ zadnjim potovanjem Jana $\mathrm{z}$ Jenštejna $\mathrm{v}$ Rim $\mathrm{v}$ drugi polovici leta 1398, ko še ni dokončal dela pri epistolariju, nekateri konvoluti pa so za vselej ostali na Češkem. 


\section{Bibliografija}

\section{Viri}

Adalbertus Ranconis De Ericinio, Miscellanea, Praga, Knihovna pražské metropolitní kapituly, N 8.

Johannes de Jenczenstein, Codex epistolaris, Praga, Národní archiv, Fond češke dvorne pisarne, cod. 147 (olim: Državni centralni arhiv, zbirka: Rokopisi različnih provenienc, rkp. 2449).

John Wycliff, Articuli, Stockholm, Kungliga Biblioteket, Codex Holmensis A 164.

Liber decanorum facultatis philosophicae Universitatis Pragensis, Praga, Národní knihovna České republiky, Sign. VIII E 7.

Petrus de Zittau, Chronicon Aulae regiae (= Zbraslavska kronika alias Königssaaler Chronik), Biblioteca Apostolica Vaticana, Vat. Lat. 1122.

Liber decanorum facultatis philosophicae Universitatis Pragensis ab anno Christi 1367 usque ad annum 1585, Pragae 1983 (faksimile).

Vita Johannis de Jenczenstein (Fontes rerum Bohemicarum I, izd. Joseph Emler), Pragae 1873.

\section{Literatura}

Gumbert, J. P., Manuscripts of Historians in the Northern Netherlands, v: Medieval Autograph Manuscripts. Proceedings of the XVII th Colloquium of the Comité International de Paléographie Latine (ur. Golob, N.), Bibliologia vol. 36, Turnhout 2013, str. 39-48.

Kadlec, J., Leben und Schriften des Prager Magisters Adalbert Rankonis de Ericinio, Münster 1971.

Loserth, J., Der Codex epistolaris des Erzbischofs von Prag Johann von Jenzenstein, Beiträge zur Geschichte der hussitischen Bewegung I, Wien 1877, str. 267-400.

Marek, J., Jakoubek ze Stříbra a počátky utrakvistického kazatelství v českých zemích, Praha 2011.

Molnár, A., Pohled do Husovy literární dílny, Listy filologické 82, 1959, str. 239-244.

Polc, J. V., Proč nebyl arcibiskup Jan z Jenštejna svržen do Vltavy, Medievalia Historica Bohemica, 4, Praha 1995, str. 199-220 (reprint: Polc, J. V., Česká církev v dějinách, Praha 1999, str. 293-316).

Polc, J. V., Jean de Jenstejn, Dictionaire de Spiritualité VIII, col. 558-565 (reprint v: Polc, J. V., Česká církev v dějinách), Praha 1999, str. 241-253. 
Pumprova, A., Svědectví autografu o práci Petra Žitavského s textem Zbraslavské kroniky, Časopis Matice moravské 131, 2012, str. 239-263.

Spunar, P., Nový autograf M. J. Husi?, Listy filologické 82, 1959, str. 235-238 in Listy filologické 83, 1960, str. 116-122.

Spunar, P., Repertorium auctorum Bohemorum provectum idearum post Universitatem Pragensem conditam illustrans I, Studia Copernicana XXV, Ossolineum 1985.

Steffens, F., Lateinische Paläeographie. 125 Tafeln in Lichtdruck mit gegenüberstehender Transkription nebst Erläuterungen und einer systematischen Darstellung, Trier $1909 .^{2}$

Trottmann, Chr., pod geslom: Giovanni XXII., v: Enciclopedia dei Papi, Roma 2000, str. 512-521, bibliografska priloga.

Weltsch, R. E., Archbishop John of Jenstein (1348-1400). Papalism, Humanism and Reform in Pre-Hussite Prague, Studies in European History VIII, The Hague, Paris 1968. 
Zdeňka Hledíková

\section{Lastnoročne opombe in korekture Jana z Jenštejna v njegovem epistolariju}

Ključne besede: Jan z Jenštejna, epistolarij, avtograf, avtorjevi popravki, 14. stoletje, latinska besedila na Češkem

Med avtografi učenjakov iz poznega srednjega veka so le redki takšni, katerih besedilo je prenesel na papir pomočnik, popravil pa avtor. Takšni rokopisi so pomenili osnovo za dokončne prepise, preden je bilo delo predstavljeno širši javnosti. Takšen prehodni tip kodeksa predstavlja zbirka pisem nadškofa Jana $z$ Jenštejna $s$ konca 14.stoletja; pod naslovom »Jenštejnov epistolarij« je besedila objavil leta 1877 J. Loserth. - Prispevek se je osredotočil na ureditev leg ter na značaj in zaporedje prepisanih pisem, pa tudi na popravke, ki jih je naredil drug pisar. Sklepna ugotovitev se glasi, da je rokopis nastal pod neposrednim nadzorom nadškofa, ki je posamezna pisma postopoma izročal kopistu, nato pa jih je je stilistično izpilil in popravil. Epistolarij ni dočakal prepisa v dokončno obliko, namenjeno javnosti. 


\section{Jan of Jenštejn's Personal Hand Corrections in his Epistolary}

Keywords: Jan of Jenštejn, Epistolary, autograph, corrections by the author, the $14^{\text {th }}$ century, Latin texts in Czech lands

Among autographs by learned men of the late Middle Ages are only a few manuscripts written by an auxiliary copyist but corrected by the author of the text. Such manuscripts served as foundations for end-transcriptions of works destined for the public at large. The collection of $14^{\text {th }}$-century letters by Archbishop Jan of Jenštejn, published in 1877 as Jenštejn's Epistolary, represent such a transient codex-typus. The article focuses on the adjustment of the quires and character and order of the letters copied, as well as on the text corrections made by another scribe. It concludes that the manuscript originated under the direct supervision of the archbishop, who transmitted the papers of individual letters to the scribe step by step for copying, and then polished their stylistic form and corrected them. The epistolary has never been transcribed into a definitive form for the public. 